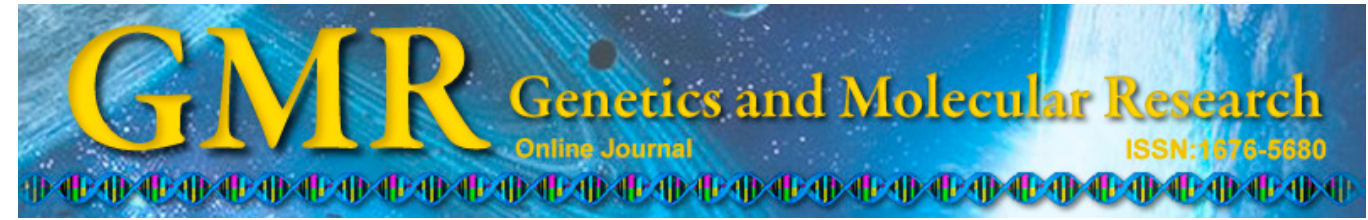

\title{
Mitochondria-dependent apoptogenic activity of the aqueous root extract of Croton membranaceus against human BPH-1 cells
}

\author{
D.K. Afriyie ${ }^{1,3}$, G.A. Asare', K. Bugyei ${ }^{3}$, J. Lin'1, J. Peng' ${ }^{1}$ and Z. Hong' \\ ${ }^{1}$ Academy of Integrative Medicine, \\ Fujian University of Traditional Chinese Medicine, China \\ ${ }^{2}$ Department of Medical Laboratory Sciences, \\ School of Allied Health Sciences, Accra, Ghana \\ ${ }^{3}$ Department of Pharmacology, University of Ghana Medical School, Accra, Ghana \\ Corresponding authors: G.A. Asare / Z. Hong \\ E-mail: gasare@chs.edu.gh / zxyyjy@fjtcm.edu.cn
}

Genet. Mol. Res. 14 (1): 149-162 (2015)

Received February 11, 2014

Accepted October 8, 2014

Published January 15, 2015

DOI http://dx.doi.org/10.4238/2015.January.15.18

\begin{abstract}
Croton membranaceus aqueous root extract (CMARE) is among the widely used phytotherapeutics in Ghana for the management of benign prostatic hyperplasia (BPH) and prostate cancer. However, the mechanism of action of CMARE remains to be elucidated. This study aimed to establish whether apoptosis is involved in the antiproliferative effect of CMARE on human BPH-1 cells. We determined the effect of treatment with $0,1,3$, and $5 \mathrm{mg} / \mathrm{mL}$ CMARE for 24,48 , and $72 \mathrm{~h}$ on the viability and morphology of BPH-1 cells using the MMT assay and phase-contrast microscopy, respectively. We examined the apoptosisinducing effects of CMARE after $48 \mathrm{~h}$ at the cellular level using Hoescht 33258 and JC-1 dye staining and flow cytometry analysis. We performed reverse transcription polymerase chain reaction and Western blotting to confirm the apoptotic effects of CMARE at the molecular level. CMARE induced a significant dose-dependent inhibition in the proliferation of BPH-1 cells $(\mathrm{P}<0.05)$ and an alteration in their
\end{abstract}


morphology and a reduction their density. Furthermore, CMARE induced dose-dependent staining of the nuclear chromatin, significant DNA fragmentation with $\mathrm{G}_{0} / \mathrm{G}_{1}$ sub-diploid cells $(\mathrm{P}<0.01)$, and loss of the mitochondrial membrane potential in the treated cells compared to the controls after $48 \mathrm{~h}(\mathrm{P}<0.01)$. Additionally, while CMARE induced a significant upregulation of the mRNA and protein levels of $\mathrm{Bax}$, those of $\mathrm{Bcl}_{2}$ did not change significantly. Therefore, induction of mitochondria-dependent apoptosis of BPH-1 cells may be a possible mechanism of action of CMARE.

Key words: Croton membranaceus; $\mathrm{BPH}-1$ cells; Proliferation; Cell cycle; Apoptosis

\section{INTRODUCTION}

Benign prostatic hyperplasia (BPH) and prostate cancer have a high impact on public health; BPH is observed mostly in men older than 50 years. Approximately $42 \%$ of men aged 51-60 years, $70 \%$ of men aged $61-70$ years, and almost $90 \%$ of men aged $81-90$ years have BPH (Tanguay et al., 2009). Enlargement of the prostate often results in lower urinary tract symptoms, which have a negative impact on the quality of life of patients (Kramer et al., 2007). Despite the increase in the incidence and prevalence of BPH, its etiology and pathophysiology remain to be clarified. The growth of prostate cells is governed by a delicate balance between cell proliferation and apoptosis (Kyprianou and Jacobs, 1996). Although the normal stroma to epithelium ratio of the prostate is 2:1, in patients with $\mathrm{BPH}$, this ratio is 5:1 (Prabhav and Bairy, 2009). A previous study showed that excessive proliferation of the stromal and epithelial cells (37-fold and 9-fold, respectively) was observed in some patients with BPH (Claus et al., 1993). This finding indicates that an imbalance of the molecular mechanisms of proliferation and apoptosis is involved in the development of BPH and prostate cancer.

Apoptosis or programmed cell death, which occurs as a normal and controlled part of growth, is generally observed in eukaryotic cells. This process is genetically controlled, and a defect in the apoptotic process may lead to the development of neoplasms. Apoptosis can be induced by a variety of intrinsic and extrinsic stimuli such as hormones, DNA damage, growth factors, chemotherapeutic agents, and ionizing radiation. Many proteins are involved in the cellular apoptosis pathway, and the Bcl-2 family proteins have emerged as vital regulators of the intrinsic apoptotic pathway (mitochondria-mediated apoptosis) by functioning as either promoters (e.g. Bax and Bak) or inhibitors such as Bcl-2 and Bcl-xL (Chao and Korsmeyer, 1998).

Studies on cell viability, proliferation, and apoptosis are vital for evaluating the response of a cell population to chemotherapeutic agents and growth factors for the BPH drug development (Hong et al., 2012). Furthermore, therapeutic agents that can inhibit cell growth and/or induce apoptosis have emerged as potential targets for optimizing the treatment of $\mathrm{BPH}$ and prostate cancer. However, management of cancers require novel therapies that are affordable, non-toxic to normal cells, and can delay the onset and/or progression of the condition with minimal side effects (Singh et al., 2005). Currently, phytotherapeutic agents have attracted tremendous attention for the treatment of BPH and prostate cancer, because they are safer, more cost-effective, and have fewer side effects than conventional alternatives (Thompson, 2001; Arora et al., 2003). 
Croton membranaceus Mull. Arg (Euphorbiaceae) is a medicinal plant that has been used for decades in Ghana for the management of BPH and prostate cancer. Previous in vitro studies revealed that the ethanolic root extract of C. membranaceus was cytotoxic to the normal and cancerous cells of the human prostate (Bayor et al., 2008). Preclinical toxicity studies indicate that the ethanolic root extract of C. membranaceus is generally non-toxic (Asare et al., 2011; Afriyie et al., 2013a). Recent in vivo studies showed that the aqueous root extract of $C$. membranaceus causes a significant inhibition in the proliferation of glandular epithelial cells and a decrease in the serum prostate-specific antigen levels (Afriyie et al., 2013b). However, the mechanism underlying the therapeutic effect of $C$. membranaceus on the prostate cells has not been elucidated thus far. Additionally, histological examination of the C. membranaceustreated prostate shows growth inhibition (Afriyie et al., 2013b). We therefore hypothesized that the cytotoxic effect on the prostate cells may be because of induction of apoptosis. In this study, we investigated the effects of the aqueous root extract of C. membranaceus (CMARE) on the viability and apoptosis of human BPH-1 cells.

\section{MATERIAL AND METHODS}

\section{Reagents}

Rosewell Park Memorial Institute Medium 1640 (RPMI 1640), trypsin-ethylenediaminetetraacetic acid (Trypsin-EDTA), 5,5',6,6'-tetrachloro-1,1',3,3'-tetraethybenzimidazolylcarbocyarine iodide (JC-1), bis-benzimidazole dye Hoescht 33258 assay kit, and TriZol reagent were purchased from Invitrogen (California, USA). Bcl-2, Bax, $\beta$-actin antibodies and secondary horseradish peroxidase (HRP)-conjugated antibodies were purchased from Santa Cruz Biotechnology (Texas, USA). Cell cycle assay kit was purchased from BD Biosciences (California, USA). Penicillin-streptomycin, 10\% fetal bovine serum (FBS), and methythiazolyltetrazolium (MTT) were obtained from Sigma Chemicals (St. Louis, USA). Other reagents used were phosphate-buffered saline (PBS; Thermo Scientific, Florida, USA), 0.25\% trypsin (Hyclone, Utah, USA), and Promega SuperScript II reverse transcriptase (Wisconsin, USA). All other chemicals, unless stated, were obtained from Sigma Chemicals (St. Louis, USA).

\section{Cell culture}

Human BPH-1 cells were kindly provided by Professor Zhengfeng Hong (Academy of Integrative Medicine, Fujian University of Traditional Chinese Medicine, China). Cells were cultured in RPMI 1640 medium (L-glutamine) containing 10\% (v/v) FBS, 100 Units/ $\mathrm{mL}$ penicillin, and $100 \mu \mathrm{g} / \mathrm{mL}$ streptomycin and were maintained at $5 \% \mathrm{CO}_{2}$ in a humidified incubator at $37^{\circ} \mathrm{C}$.

\section{Extraction of CMARE}

The roots of C. membranaceus were harvested in December 2012, authenticated, and the aqueous extract was obtained as described by Afriyie et al. (2013a). The freeze-dried extract was weighed and stored in a sealed container in a refrigerator at a temperature of $5^{\circ} \pm$ $3^{\circ} \mathrm{C}$ until use. 


\section{Preparation of phosphate-buffered solution of CMARE}

To enhance complete dissolution of the CMARE powder, PBS was used as a solvent to prepare a stock solution of $200 \mathrm{mg} / \mathrm{mL}$. The CMARE was diluted further using the RPMI 1640 medium (L-Glutamine) in 10\% FBS to obtain the required working concentrations.

\section{MTT assay for cell viability}

BPH- 1 cells were seeded on 96-well plates at a density of $1.0 \times 10^{5}$ cells/well in 0.1 $\mathrm{mL}$ medium in $10 \% \mathrm{FBS}$. Then, the cells were treated with various concentrations of CMARE $(0,1,3$, and $5 \mathrm{mg} / \mathrm{mL})$ and incubated for 24,48 , and $72 \mathrm{~h}$. At the designated times after drug treatment, $10 \mu \mathrm{L}$ MTT ( $5 \mathrm{mg} / \mathrm{mL}$ in PBS) was added to each well, and the plates were incubated for $4 \mathrm{~h}$ at $37^{\circ} \mathrm{C}$. Subsequently, the plates were removed, and $100 \mu \mathrm{L}$ dimethyl sulfoxide was added to dissolve the purple-blue MTT formazan crystals. The absorbance was read at a wavelength of $570 \mathrm{~nm}$ using an enzyme-linked immunosorbent assay (ELISA) microplate reader (Model EXL 800; Bio-Tek, Florida, USA). All experiments were performed in triplicates. The percentage cellular viability was calculated with the appropriate controls taken into consideration as follows: Cell viability $(\%)=$ average $\mathrm{OD}_{\text {treatment group }} /$ average $\mathrm{OD}_{\text {blank group }} \times 100 \%$.

\section{Assessment of changes in cell morphology}

BPH-1 cells were seeded on 6-well plates at a density of $1.0 \times 10^{5}$ cells/well in $2 \mathrm{~mL}$ culture medium (with 10\% FBS) and were incubated for $24 \mathrm{~h}$. After the designated time, the cells were treated with the increasing concentrations of CMARE $(0,1,3$, and $5 \mathrm{mg} / \mathrm{mL})$ for $48 \mathrm{~h}$. Cell morphology was observed using a phase-contrast microscope (Olympus, Tokyo, Japan). Photomicrographs were taken at a magnification of 200X.

\section{Detection of apoptosis using Hoescht 33258 staining}

BPH-1 cells were seeded on two 6-well plates at a density of $1.0 \times 10^{5}$ cells/well in $2 \mathrm{~mL}$ culture medium (with $10 \%$ FBS). After incubation for $24 \mathrm{~h}$, the cells were treated with various concentrations of CMARE $(0,1,3$, and $5 \mathrm{mg} / \mathrm{mL})$. After $48 \mathrm{~h}$, BPH- 1 cells were fixed in 4\% neutral formaldehyde for $30 \mathrm{~min}$, washed with PBS for $5 \mathrm{~min}$, and stained with $10 \mu \mathrm{L}$ Hoescht 33258 dye at $37^{\circ} \mathrm{C}$ for $30 \mathrm{~min}$ in the dark. The Hoescht 33258 exhibited high fluorescence on binding to the double-stranded DNA. The shape of the nucleus and chromatin condensation were detected in the live and apoptotic cells using Hoescht 33258 and were examined using fluorescence microscopy. Then, photomicrographs of BPH-1 cells were taken at a magnification of 200X under a fluorescent phase-contrast microscope.

\section{Examination of mitochondrial membrane potential using JC-1 staining}

$\mathrm{BPH}-1$ cells were seeded on 6-well plate at a density of $1 \times 10^{5}$ cells/well in $2 \mathrm{~mL}$ medium in $10 \% \mathrm{FBS}$. After incubation for $24 \mathrm{~h}$, the cells were treated with various concentrations of CMARE $(0,1,3$, and $5 \mathrm{mg} / \mathrm{mL})$ for $48 \mathrm{~h}$. BPH-1 cells $\left(1 \times 10^{5}\right)$ in each group were "collected" after trypsinization with $0.25 \%$ trypsin and were incubated with $10 \mu \mathrm{g} / \mathrm{mL} \mathrm{JC}-1$ dye (Invitrogen) at $37^{\circ} \mathrm{C}$ and $5 \% \mathrm{CO}_{2}$ for $30 \mathrm{~min}$. To examine the loss of mitochondrial membrane 
potential, we stained the cells with fluorescent JC-1 dye. The JC-1 dye is a cationic dye that indicates mitochondrial potential during the apoptosis of cells by shift of fluorescence emission from green to red. The mitochondrial membrane potential was assessed by analyzing the red and green fluorescence after using flow cytometry analysis via fluorescence-activated cell sorting (FACS) caliber (Becton Dickinson, California, USA).

\section{Detection of background aggregate and debris using flow cytometry analysis}

BPH-1 cells were seeded on 6-well plates at a density of $1.0 \times 10^{5}$ cells/well in $2 \mathrm{~mL}$ culture medium in $10 \%$ FBS. After incubation for $24 \mathrm{~h}$, the cells were treated with various concentrations of CMARE $(0,1,3$, and $5 \mathrm{mg} / \mathrm{mL})$ for $48 \mathrm{~h}$. The cells were treated further with $0.25 \%$ trypsin and washed with PBS. We observed the progression of cells through the different phases of the cell cycle phases, and determined the proportion of BPH-1 cells undergoing apoptosis, which is the percentage of background aggregate and debris (BAD) in sub-diploid $\mathrm{G}_{0} / \mathrm{G}_{1}$ peak, using Cycle-test Plus DNA assay kit (BD Biosciences, NJ, USA) using a flow cytometer (BD Biosciences) according to manufacturer instructions.

\section{RNA extraction and RT-PCR analysis}

To determine RNA expression, we seeded the BPH-1 cells into $25 \mathrm{~cm}^{2}$ flasks (1.5 x $10^{5} / \mathrm{mL}$ ) in $5 \mathrm{~mL}$ culture medium (with $10 \% \mathrm{FBS}$ ). After $24 \mathrm{~h}$, the cells were treated with various concentrations of CMARE $(0,1,3$, and $5 \mathrm{mg} / \mathrm{mL})$ for $48 \mathrm{~h}$. We isolated total RNA from the BPH-1 cells using the TriZol reagent. Oligo (dT)-primed RNA $(1 \mu \mathrm{g})$ was reversetranscribed using SuperScript II reverse transcriptase according to manufacturer instructions. The cDNA obtained was used to determine the mRNA expression levels of Bax and Bcl-2 using PCR with Taq DNA polymerase (Fermentas). GAPDH was used as an internal control. Primer sequences used for the amplification of Bax, Bcl-2, and GAPDH transcripts were as follows: Bax forward, 5'-TGC TTC AGG GTT TCA TCC AGG-3' and reverse 5'-TGG CAA AGT AGA AAA GGG CGA-3'; Bcl-2 forward, 5'-CAG CTG CAC CTG ACG CCC TT-3' and reverse 5'-GCC TCC GTT ATC CTG GAT CC-3'; GAPDH forward, 5'-GTC ATC CAT GAC AAC TTT GG-3' and reverse 5'-GAG CTT GAC AAA GTG GTC GT-3'.

\section{Western blot analysis}

BPH-1 cells $\left(1.5 \times 10^{5} / \mathrm{mL}\right)$ were seeded into $25-\mathrm{cm}^{2}$ culture flasks in $5 \mathrm{~mL}$ medium for $24 \mathrm{~h}$. After the designated time, the cells were treated with the various concentrations of CMARE for $48 \mathrm{~h}$ and lysed with mammalian cell lysis buffer containing protease and phosphatase inhibitor cocktails. The lysates were separated using $12 \%$ sodium dodecyl sulfate-polyacrylamide electrophoresis gel (SDS-PAGE). The proteins were electrophoretically transferred onto polyvinylidene difluoride (PVDF) membranes and then blocked using 5\% skimmed milked at room temperature for $2 \mathrm{~h}$. Then, the membranes were washed in TBS with $0.25 \%$ Tween-20 (TBST) and probed with primary antibodies against Bax, Bcl-2, and $\beta$-actin $(1: 1,000)$ overnight at $4^{\circ} \mathrm{C}$. $\beta$-Actin was used as an internal control. The membranes were washed in TBST, and secondary HRP-conjugated anti-rabbit antibodies (Cell Signaling Technology, Oregon, USA) were added at a dilution of 1:2500, and the membranes were incubated for $2 \mathrm{~h}$ at room temperature. The membranes were finally washed in TBST, analyzed with 
ECL Plus reagents and scanned using Storm PhosphorImager (ChemiDoc XRS+; Bio-Rad, California, USA).

\section{Statistical analysis}

Statistical analysis was performed using the Graph Pad Software version 5.0 for windows (Graph Pad Software, California, USA), and data are reported as means \pm SE of at least triplicate experiments. Significant differences between the treated groups and control were evaluated by performing a one-way analysis of variance (ANOVA). Where ANOVA showed significant differences, post-hoc analysis was performed using Bonferroni multiple comparison test. $\mathrm{P} \leq 0.05$ was considered to be statistically significant.

\section{RESULTS}

\section{CMARE inhibits the proliferation of BPH-1 cells}

We determined the viability of BPH-1 cells after treatment with various concentrations of CMARE $(0,1,3$, and $5 \mathrm{mg} / \mathrm{mL})$ for 24,48 , and $72 \mathrm{~h}$ using the MTT assay; we compared the relative number of cells in the BPH-1 monolayer treated with CMARE with those in the untreated controls. Cultures with more than $90 \%$ viable cells were considered unaffected, those with $80-90 \%$ viable cells were modestly affected, and cultures with $<80 \%$ viable cells were considered to have cytotoxic effects of the compound (Hostanska et al., 2007). Cells treated with $1 \mathrm{mg} / \mathrm{mL}$ CMARE for $24-72 \mathrm{~h}$ showed $95-84 \%$ viability compared to that of the control cells. Furthermore, treatment with 3 and $5 \mathrm{mg} / \mathrm{mL}$ CMARE for 48-72 $\mathrm{h}$ decreased the $\mathrm{BPH}-1$ cell viability to $79-42 \%$ and $61-25 \%$, respectively, compared to that of the controls $(\mathrm{P}<$ 0.05 and 0.001 , respectively). CMARE induced a dose- and time-dependent decrease in BPH1 cell viability (Figure 1). Examination of the BPH-1 cells under a phase-contrast microscope showed that treatment with CMARE for $48 \mathrm{~h}$ induced a significant dose-dependent alteration in the morphology and a reduction in the density of BPH-1 cells (Figure 2).

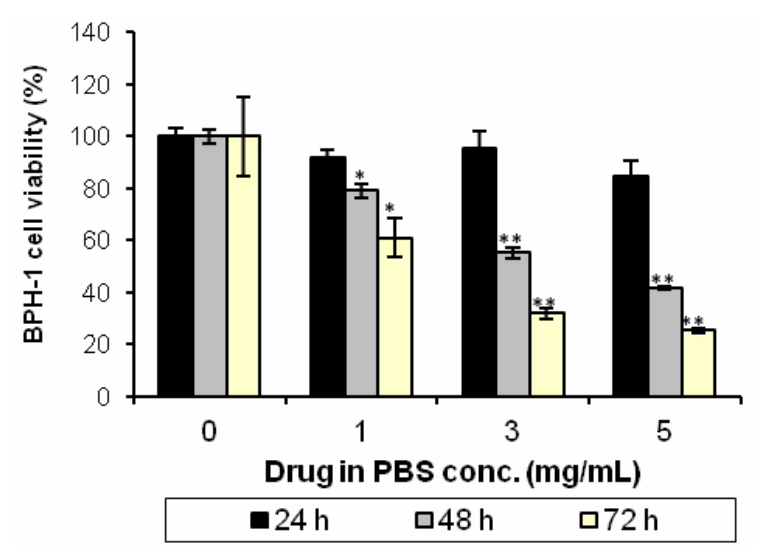

Figure 1. Graph showing the effect of Croton membranaceus aqueous root extract (CMARE) on the viability of BPH-1 cells at 24, 48, and $72 \mathrm{~h}$. Data are reported as means \pm standard error (SE) from at least three independent experiments. ${ }^{*} \mathrm{P}<0.05$ compared to control (untreated). $* * \mathrm{P}<0.001$ compared to control (untreated). 

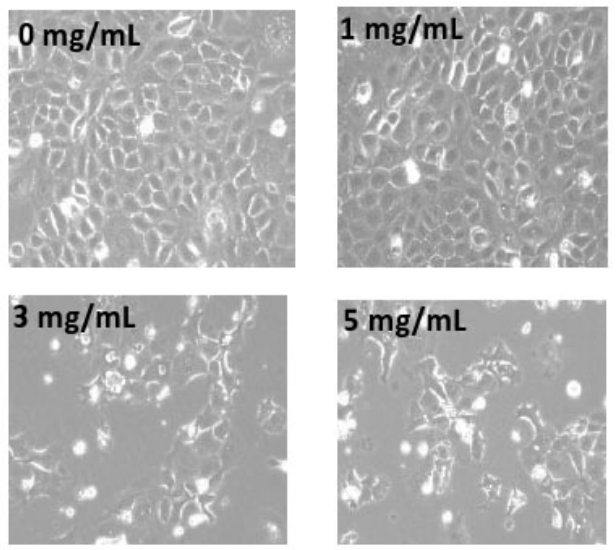

Figure 2. Photomicrographs obtained at $200 \mathrm{X}$ magnification showing dose-dependent effects of various concentrations of Croton membranaceus aqueous root extract (CMARE) on the confleuncy of BPH-1 cells after $48 \mathrm{~h}$. Images are representative of three independent experiments.

\section{CMARE induces an alteration in the nuclear morphology of BPH-1 cells}

To ascertain whether apoptosis was involved in the antiproliferative activity of CMARE, we analyzed nuclear chromatin condensation in BPH-1 cells using Hoescht 33258. After $48 \mathrm{~h}$ of exposure of BPH-1 cells to various concentrations of CMARE $(0,1,3$, and 5 $\mathrm{mg} / \mathrm{mL}$ ), the cells were stained using the Hoescht 33258 dye. The number of brightly stained blue apoptotic cells was significantly higher in the BPH-1 cells treated with $1 \mathrm{mg} / \mathrm{mL}$ CMARE than the control cells, which displayed weak fluorescence (Figure 3). BPH-1 cells treated with 3 and $5 \mathrm{mg} / \mathrm{mL}$ of CMARE showed a significant decrease in the number of cells after $48 \mathrm{~h}$, and compared to the untreated control cells, the treated cells showed brightly stained blue condensed chromatin and fragmented nuclear morphology.
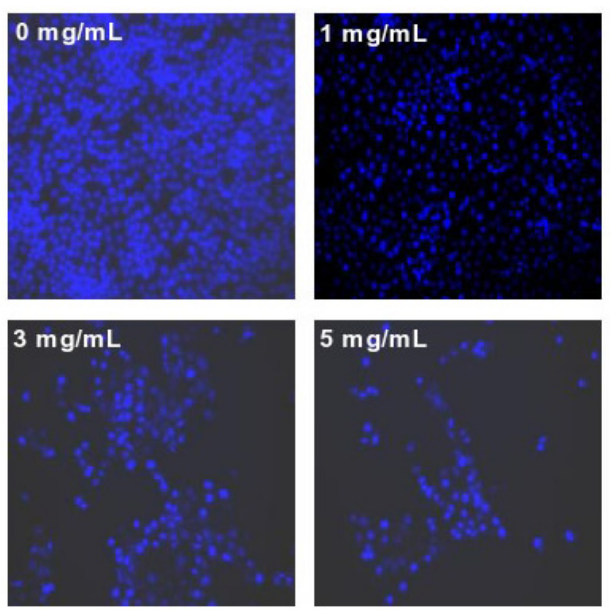

Figure 3. Hoescht 33258 staining showing brightly blue stained condensed chromatin in BPH-1 cells treated with various concentrations of Croton membranaceus aqueous root extract (CMARE) after $48 \mathrm{~h}$. 


\section{Effect of CMARE on the mitochondrial potential $(\triangle \psi \mathrm{m})$ of BPH-1 cells}

We examined the characteristic loss of the mitochondrial potential in the apoptotic cells in relation to the high mitochondrial potential of healthy cells using FACS analysis with JC-1 dye staining. JC-1 selectively enters the mitochondria of healthy cells to form complex aggregates that emit intense red fluorescence $(590 \mathrm{~nm}, \mathrm{FL} 2)$; a shift from the intense red to bright green fluorescence ( $525 \mathrm{~nm}, \mathrm{FL}-1)$ is an indication of the loss of membrane potential. Our data showed that the percentages of JC-1 green bright BPH-1 cells treated with 1, 3, and $5 \mathrm{mg} / \mathrm{mL}$ CMARE were significantly higher, $13.1 \pm 1.5 \%, 32.4 \pm 5.1 \%$, and $36.1 \pm 1.7 \%(\mathrm{P}<$ 0.01 ), respectively, than the untreated cells $5.6 \pm 1.3 \%$ (Figure $4 \mathrm{~A}$ and $\mathrm{B}$ ).

A
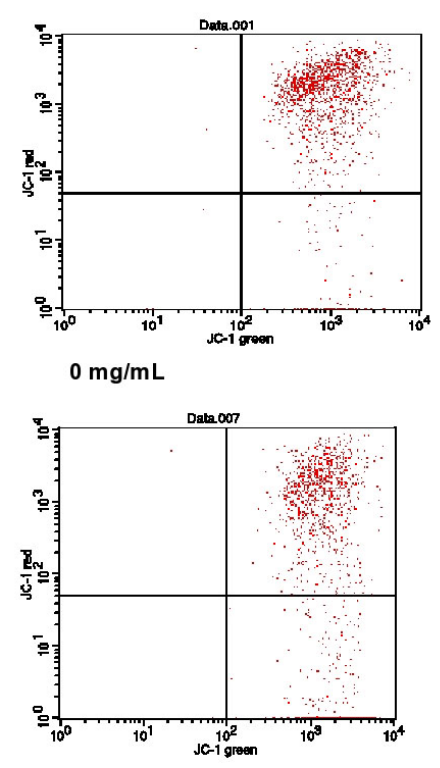

$3 \mathrm{mg} / \mathrm{mL}$
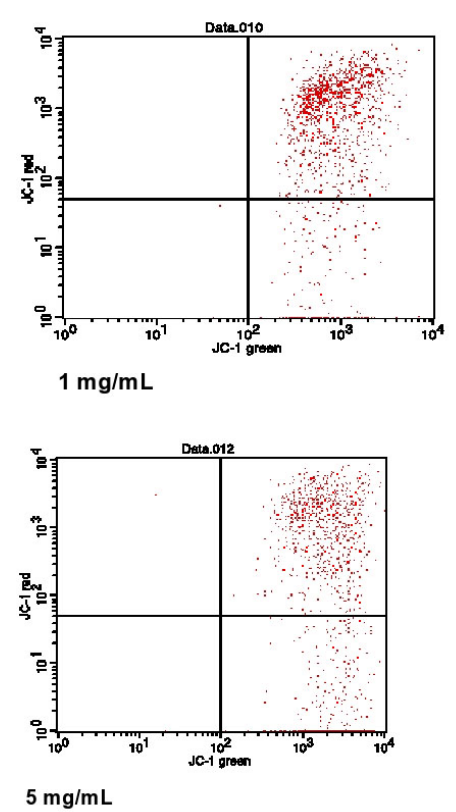

$5 \mathrm{mg} / \mathrm{mL}$

B

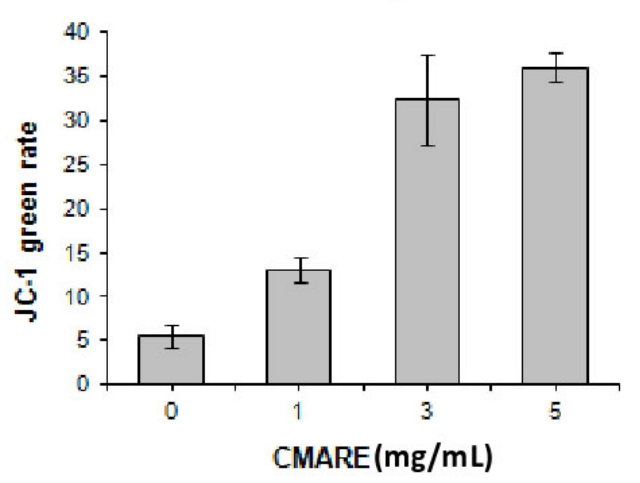

Figure 4. A. Effect of various concentrations of Croton membranaceus aqueous root extract (CMARE) on the mitochondrial membrane potential of BPH-1 cells after $48 \mathrm{~h}$. Data are representative of three independent experiments. B. Bar charts showing dose-dependent loss of mitochondrial membrane potential in BPH-1 cells treated various doses of Croton membranaceus aqueous root extract (CMARE) after $48 \mathrm{~h}$. CMARE induced background aggregate and debris (BAD) in BPH-1 cells. 


\section{CMARE induces BAD in BPH-1 cells}

To further ascertain whether the antiproliferative activity of CMARE was caused by DNA fragmentation induced by apoptosis, we analyzed the proportion of BAD during BPH-1 cell cycle progression after treatment with various concentrations of CMARE. After $48 \mathrm{~h}$ of treatment with 1,3 , and $5 \mathrm{mg} / \mathrm{mL}$ CMARE, the proportion of BAD in the cells was $2.63 \pm$ $0.56,4.68 \pm 0.52$, and $6.0 \pm 0.21 \%$, respectively, which was significantly higher $(\mathrm{P}<0.01)$ than that present in the untreated control cells, $3.48 \pm 0.56 \%$, except that present in the $1 \mathrm{mg} /$ $\mathrm{mL}$ dose group. We observed a dose-dependent increase in the induction of apoptosis as shown by the presence of sub-diploid peaks $\left(\mathrm{G}_{0} / \mathrm{G}_{1}\right)$ in only the treated cells. The proportion of BAD in the BPH-1 cells is a measure of the rate of apoptosis (apoptosis index) (Figures 5 and 6).

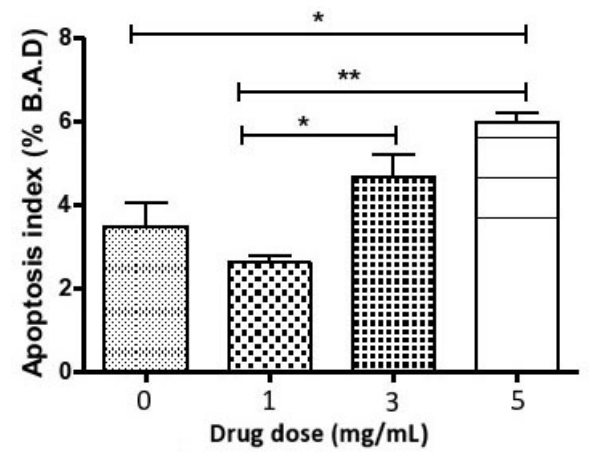

Figure 5. Bar chart showing flow cytometry analysis of percent background aggregate and debris (BAD) in Croton membranaceus aqueous root extract (CMARE)-treated BPH-1 cells. Data are reported as means \pm standard error (SE). Significant differences $(* \mathrm{P}<0.05$ or $* * \mathrm{P}<0.01)$ between CMARE-treated and untreated control cells.
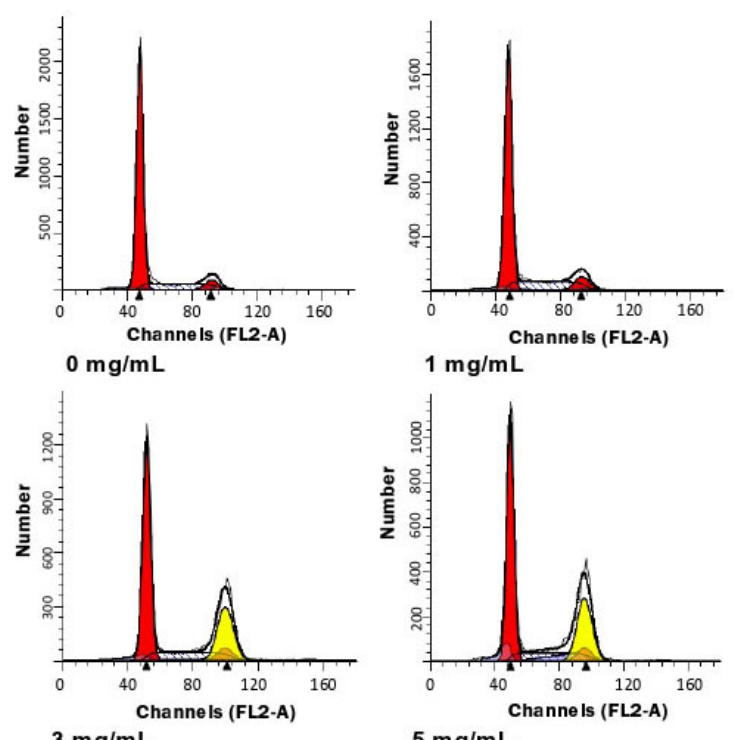

Figure 6. Flow cytometry graphs depicting cell cycle distribution and presence of sub-dipliod $\mathrm{G}_{0} / \mathrm{G}_{1}$ peaks in BPH-1 cells treated with Croton membranaceus aqueous root extract (CMARE) for $48 \mathrm{~h}$ compared to those in the untreated control cells. 


\section{Effect of CMARE on Bcl-2 family proteins}

To understand the mechanism of apoptosis induction by CMARE in BPH-1 cells, we examined the effect of the CMARE extract on the mRNA and protein levels of Bax and Bcl-2 using real-time PCR and Western blot analysis. CMARE induced a significant dose-dependent increase in the expression levels of Bax mRNA. However, increasing doses of CMARE did not show a significant increase in the mRNA expression level of Bcl-2 (Figure 7).

A

Bax

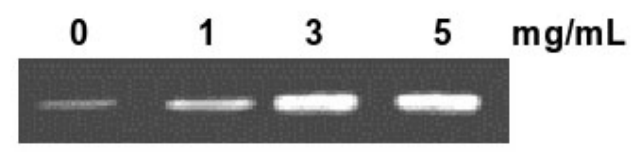

$\mathrm{Bcl}-2$

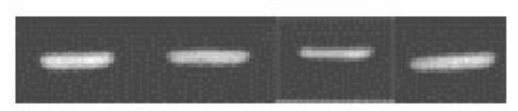

GADPH

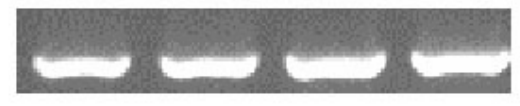

B

Bax

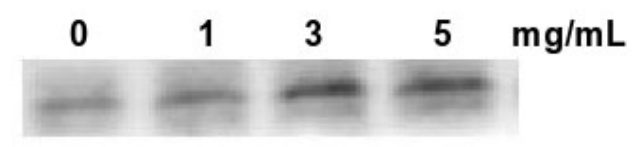

Bcl-2

B-actin

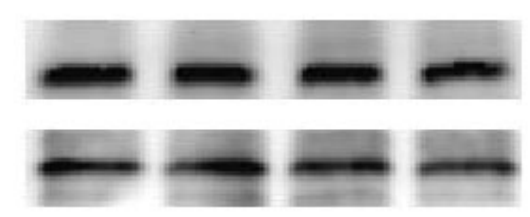

Figure 7. A. Effect of 48-h treatment with Croton membranaceus aqueous root extract (CMARE) on the mRNA expression levels of $\mathrm{Bax}$ and $\mathrm{Bcl}-2$ in $\mathrm{BPH}-1$ cells determined using reverse transcription polymerase chain reaction (RT-PCR). GADPH was used as an internal control. B. Effect of 48-h treatment with Croton membranaceus aqueous root extract (CMARE) on the levels of Bax and Bcl-2 proteinsin BPH-1 cells determined using Western blot analysis.

\section{DISCUSSION}

Although the exact pathogenesis of BPH and prostate cancer is still not clearly understood, several studies show that reduction of apoptosis is associated with the development of BPH (Siegfried et al., 1993; Kyprianou et al., 1996). Hence, induction of apoptosis has emerged as a potential target for optimizing the medical treatment for $\mathrm{BPH}$ and prostate cancer. Prostate epithelial cells derived from normal humans and BPH patients that have undergone prostatectomy are useful in vitro models for examining the cause of BPH and determining the mechanism of action of potential novel therapies (Kaseb et al., 2007). Medicinal plant extracts often contain diverse biologically active compounds with different mechanisms of action. Thus, whether apoptosis is one of the mechanisms of action of the medicinal plants used in improving symptoms associated with BPH and prostate cancers remains to be established. 
A previous study has shown the cytotoxic activity of the methanolic root extracts of C. membranaceus against human normal and cancerous prostate cells in vitro (Bayor, 2008). However, to the best of our knowledge, this is the first in vitro study in which the effect of CMARE on BPH-1 cells has been examined. Our study showed that CMARE treatment induced a significant dose- and time-dependent decrease in the viability of BPH-1 cells. Our results are consistent with the results of significant antiproliferative activity of CMARE observed in the epithelial and stromal cells of Sprague-Dawley rats reported previously (Afriyie at al., 2013b). Furthermore, the significant decrease in the viability of BPH-1 cells observed in our study was similar to that observed in previous in vitro studies performed using extracts from plants such as Olea europaea, Serenoae repentis fructus, and Commiphora mukul used for the management of BPH and/or prostate cancer (Acquaviva et al., 2012; Hostanska et al., 2007). Additionally, our results showed that significant inhibition of BPH-1 cells was observed only after $48 \mathrm{~h}$ of treatment with any of the doses administered. This observation suggests that CMARE may have a slow onset of action and/or long duration of action.

Disruption of the molecular mechanisms that regulate cell proliferation and apoptosis in stromal and epithelial cells has been implicated in both the development of BPH, and progression of prostate cancer (Kyprianou et al., 2000). Apoptosis is characterized by features such as cell shrinkage, membrane blebbing, chromatin condensation, and DNA ladder formation with multiple fragments, which are eventually engulfed by macrophages (Majno and Joris, 1995; Collins et al., 1997). These cellular and morphological alterations are established hallmarks for the induction of apoptosis and are associated with a significant increase in the apoptotic index (Bayne et al., 2000). Because apoptosis occurs through a complex signaling cascade, which is tightly regulated at multiple points by activators, effectors, and regulators, more than a single assay is required to detect and count apoptotic cells, and to determine a distinct cellular feature. Hoescht 33258 staining showed that treatment of BPH-1 cells with CMARE induced a significant dose-dependent induction of apoptosis associated with characteristic brightly stained blue cells with nuclear condensation.

Fragmentation of DNA during which is characterized by the presence of a sub-diploid peak during the $\mathrm{G}_{0} / \mathrm{G}_{1}$ phase, is also a hallmark of apoptosis (Darzynkiewicz et al., 2001; Huguenin et al., 2004). Treatment with the different doses of CMARE resulted in obvious dosedependent sub-diploid peaks during the $\mathrm{G}_{0} / \mathrm{G}_{1}$ phase, similar to findings of a related study where the administration of guggulsterone, an extract of C. mukul induced apoptosis with sub-diploid cells and significant DNA fragmentation in PC-3 human prostate cancer cells (Singh et al., 2005). The dose-dependent presence of BAD in BPH-1 cells treated with CMARE suggests the occurrence of DNA fragmentation, a characteristic hallmark of apoptosis (Cohen, 1993).

Maintenance of the mitochondrial membrane potential is fundamental for the performance and survival of cells (Mathur et al., 2000). Loss of mitochondrial potential, a key indicator of apoptosis in cells, results in insertion of proapoptotic proteins into the cell membrane, possible oligomerization of Bad, bax, Bid, or bid, and the release of cytochrome c into the cytoplasm because of the development of pores in the mitochondrial membrane (BouchierHayes et al., 2005; Armstrong, 2006). The JC-1 dye has been used in several apoptosis studies to detect the loss of mitochondrial membrane potential (Castedo et al., 2002). Our findings showed that CMARE induced a significant dose-dependent loss of mitochondrial membrane potential in the BPH-1 cells. Further studies are required to establish the role of caspase- 3 and caspase-9 to completely elucidate the apoptotic mechanism of CMARE. 
The Bcl-2 family of proteins, namely, Bax and Bcl-2, play a key role in maintaining the mitochondrial permeability by controlling and regulating the apoptotic mitochondrial events (Cory and Adams, 2002). The differential interaction among the pro-apoptotic proteins (i.e., Bax and Bak) and anti-apoptotic proteins (Bcl-2 and Bcl-xL) and other cellular proteins regulates apoptosis (Reed, 1997; Chao and Korsmeyer, 1998). The Bax/Bcl-2 ratio is useful because Bax expression is upregulated during apoptosis, Bax translocates into the mitochondria, and thus causes the release of cytochrome $\mathrm{c}$ and a decrease in the mitochondrial membrane potential (Liu et al., 2003). Our results showed that the administration of CMARE for 48 $\mathrm{h}$ induced a significant dose-dependent upregulation of mRNA and protein levels of Bax in the BPH-1 cells. However, no significant change was observed in the mRNA and protein levels of the anti-apoptotic Bcl-2 when BPH-1 cells were treated with CMARE for $48 \mathrm{~h}$. Thus, the molecular expressions of Bax and Bcl-2 observed in our study suggest an increase in the Bax/ Bcl-2 ratio in BPH-1 cells treated with CMARE and confirm the ability of CMARE to induce apoptosis at the molecular level similar to that observed at the cellular level.

Previous studies have shown that extracts from several Croton species such $C$. zambesicus, C. argyratus, and C. pierrei induce apoptosis, and these extracts are used in the management of tumors (Sandoval et al., 2002; Block et al., 2005; Morales et al., 2005). Several studies have proven the efficacy of beta-sitosterol and its glycosides in inhibiting the growth and improving the symptoms of BPH and prostate cancer (Wilt et al., 2000; Awad et al., 2005). Beta-sitosterols exhibit dose-dependent morphological and characteristic features of apoptosis such as an increase in the presence of sub $\mathrm{G}_{0} / \mathrm{G}_{1}$ population, upregulation of mRNA and protein levels of $\mathrm{Bax}$, and an increase in $\mathrm{Bax} / \mathrm{Bcl}$ ratio in $\mathrm{BPH}$, prostate cancer, and other cell lines (Duan, 2005; Park et al., 2007). Our results of the induction of apoptotic activity of CMARE are similar to those observed using extracts from other Croton species. Phytochemical investigations of the ethyl acetate fraction of the root extracts of C. membranaceus showed the presence of beta-sitosterol and beta-sitosterol-3-D-glucoside among other isolates (Bayor et al., 2007). Thus, apoptosis induced by the CMARE in BPH-1 cells may be attributed to the presence of beta-sitosterol and beta-sitosterol-3-D-glucoside similar to that observed in previous studies. The presence of these phytosterols may explain in part the mechanism of action underlying the cytotoxic effect of CMARE on prostate cancer cells in vitro (Bayor et al., 2008). Our findings support the ethnomedicinal use of CMARE in the management of prostatic tumors because of the ability of CMARE to induce apoptosis in BPH-1 cells. Further in vitro and in vivo studies are required to confirm the use of CMARE in prostate cancer cells.

In conclusion, to the best of our knowledge, our study showed for the first time that CMARE suppresses the proliferation of BPH-1 cells; and apoptosis is one of the mechanisms underlying the antiproliferative effect of CMARE. The effect of CMARE was characterized by significant nuclear condensation, DNA fragmentation, appearance of subdipliod cells, loss of membrane potential, and significant upregulation of Bax proteins. These observations provide the rationale for further preclinical and clinical studies to evaluate the efficacy of CMARE in the management of $\mathrm{BPH}$.

\section{Conflicts of interest}

The authors declare no conflict of interest. 


\section{ACKNOWLEDGMENTS}

The first author, a Pharmacist/Pharmacologist at the Ghana Police Hospital, is grateful to the Ghana Police Service Administration for granting him permission to partake in this research.

The first corresponding author is grateful to the Office of Research and Innovative Development (ORID) University of Ghana, for the travel grant provided for the study to be performed in the Academy of Integrative Medicine, Fujian University of Traditional Chinese Medicine, China. We thank Professor Zhenfeng Hong for funding the project and for permitting the usage of his facility for this study.

\section{REFERENCES}

Acquaviva R, Digiacomoi C, Sorrenti V, Galvano F, et al. (2012). Antiproliferative effect of oleuropein in prostate cell lines. Int. J. Oncol. 41: 31-38.

Afriyie DK, Asare GA, Bugyei K, Asiedu-Gyekye I, et al. (2013a). Anti-atherogenic and anti-ischemic potentials of Croton membranaceus observed during sub-chronic toxicity studies. Pharmacognosy Res. 5: 10-16.

Afriyie DK, Asare GA, Bugyei K, Asiedu-Gyekye I, et al. (2013b). Prostate specific targeting of the aqueous root extract of Croton membranaceus in experimental animals. Andrologia 1-8. Aug 19. Doi: 10.1111/and.12144.

Armstrong JS (2006). Mitochondrial membrane permeabilization: the sine qua non for cell death. Bioassays 28: 253-260.

Arora RP, Nayak RL, Malhotra V, Mohanty NK, et al. (2003). Role of herbal drugs in the management of benign prostatic hyperplasia: Clinical trial to evaluate the efficacy and safety of Himplasia. Med. Update 11: 55-58.

Asare GA, Sittie A, Bugyei K, Gyan BA, et al. (2011). Acute toxicity studies of Croton membranaceus root extract. $J$. Ethnopharmacol. 134: 938-943.

Awad AB, Burr AT and Fink CS (2005). Effect of resveratrol and beta-sitosterol in combination on reactive oxygen species and prostaglandin release by PC-3 cells. Prostaglandins Leukot. Essent. Fatty Acids 72: 219-226.

Bayne CW, Donnelly F, Ross M and Habib FK (2000). The selectivity and specificity of the actions of the lipido-sterolic extract of Serenoa repens (Permixon) on the prostate. J. Urol. 164: 876-881.

Bayor MI (2008). The Anticancer and Other Bioactivity Investigations on the Extract and Some Compounds of Croton Membranaceus (Euphorbiaceae). Doctoral thesis, Department of Pharmaceutical Chemistry, Kumasi, Ghana, Kwame Nkrumah University of Science and Technology.

Bayor MI, Ayim JSK, Philips RM, Shnyder SD, et al. (2007). The evaluation of selected Ghanaian medicinal plants for cytotoxic activities. J. Sci. Technol. 27: 16-22.

Block S, Gerkens P, Peulen O, Jolois O, et al. (2005). Induction of apoptosis in human promyelocytic leukemia cells by natural trachylobane diterpene. Anticancer Res. 25: 363-368.

Bouchier-Hayes L, Lartigue L and Newmeyer D (2005). Mitochondria: pharmacological manipulation of cell death. $J$. Clin. Invest. 115: 2640-2647.

Castedo M, Ferri K, Roumier T, Metivier D, et al. (2002). Quantitation of mitochondrial alterations associated with apoptosis. J. Immunol. Methods 265: 39-47.

Chao DT and Korsmeyer SJ (1998). BCL-2 family: regulators of cell death. Annu. Rev. Immunol. 16: 395-419.

Claus S, Aumüller G, Tunn S, Senge T, et al. (1993). Influence of hormone application by subcutaneous injections or steroid-containing silastic implants on human benign hyperplastic prostate tissue transplanted into male nude mice. Prostate 22: 199-215.

Cohen JJ (1993). Apoptosis. Immunol. Today 14: 126-130.

Collins JA, Schandi CA, Young KK, Vesely J, et al. (1997). Major DNA fragmentation is a late event in apoptosis. $J$. Histochem. Cytochem. 45: 923-934.

Cory S and Adams JM (2002). The Bcl2 family: regulators of the cellular life-or-death switch. Nat. Rev. Cancer 2: 647656.

Darzynkiewicz Z, Bedner E and Smolewski P (2001). Flow cytometry in analysis of cell cycle and apoptosis. Sem. Hematol. 38: 179-193.

Duan RD (2005). Anticancer compounds and sphingolipid metabolism in the colon. In Vivo 19: 293-300.

Hong Z, Lin J, Xiaoyong Z, Li Y, et al. (2012). Qianliening capsule inhibits human prostate cell growth via induction of mitochondria-dependent cell apoptosis. Chin. J. Integr. Med. 18: 824-830. 
Hostanska K, Suter A, Melzer J and Saller R (2007). Evaluation of cell death caused by ethanolic extract of Serenoae repentis fructus (Prostasan) on human carcinoma cell lines. Anticancer Res. 27: 873-881.

Huguenin S, Vacherot F, Kheuang L, Fleury-Feith J, et al. (2004). Antiproliferative effect of nitrosulindac (NCX 1102), a new nitric oxide-donating non-steroidal anti-inflammatory drug, on human bladder carcinoma cell lines. Mol. Cancer Ther. 3: 291-298.

Kaseb AO, Chinnakannu K, Chen D, Sivanandam A, et al. (2007). Androgen receptor and E2F-1 targeted thymoquinone therapy for hormone-refractory prostate cancer. Cancer Res. 67: 7782-7788.

Kramer G, Mitteregger D and Marberger M (2007). Is benign prostatic hyperplasia (BPH) an immune inflammatory disease? Eur. Urol. 51: 1202-1216.

Kyprianou N, Tu H and Jacobs SC (1996). Apoptotic versus proliferative activities in human benign prostatic hyperplasia. Hum. Pathol. 27: 668-675.

Kyprianou N, Chon J and Benning CM (2000). Effects of alpha(1)-adrenoceptor [alpha(1)-AR] antagonists on cell proliferation and apoptosis in the prostate: therapeutic implications in prostatic disease. Prostate (Suppl): 9: 42-46.

Liu FT, Newland AC and Jia L (2003). Bax conformational change is a crucial step for PUMA-mediated apoptosis in human leukemia. Biochem. Biophys. Res. Commun. 310: 956-962.

Majno G and Joris I (1995). Apoptosis, oncosis, and necrosis. An overview of cell death. Am. J. Pathol. 146: 3-15.

Mathur A, Hong Y, Kemp B, Barrientos AA, et al. (2000). Evaluation of fluorescent dyes for the detection of mitochondrial membrane potential changes in cultured cardiomyocytes. Cardiovasc. Res. 46: 126-138.

Morales A, Perez PP, Mendoza R, Compagnone R, et al. (2005). Cytotoxic and proapoptotic activity of ent-16 $\beta-17$ $\alpha$-dihydrokaurane on human mammary carcinoma cell line MCF-7. Cancer Letters 218: 109-116.

Park C, Moon DO, Rhu CH, Choi BT, et al. (2007). Beta-sitosterol induces anti-proliferation and apoptosis in human leukemic U937 cells through activation of caspase-3 and induction of Bax/Bcl-2 ratio. Biol. Pharm. Bull. 30: 1317-1323.

Prabhav T and Bairy L (2009). Pharmacotherapy of benign prostatic hyperplasia. J. Pharmacy BioAllied Sciences 22: 6-11.

Reed JC (1997). Bcl-2 family proteins: regulators of apoptosis and chemoresistance in hematologic malignancies. Semin. Hematol. 34: 9-19.

Sandoval M, Okuhama NN, Clark M, Angeles FM, et al. (2002). Sangre de grado Croton palanostigma induces apoptosis in human gastrointestinal cancer cells. J. Ethnopharmacol. 80: 121-129.

Siegfried C, Wrenger M, Senge T and Schulze H (1993). Immunhistochemical determination of age related proliferation rates in normal and benign hyperplastic human prostates. Urol. Res. 21: 305-308.

Singh S, Zeng Y, Xiao D, Vogel VG, et al. (2005). Caspase-dependent apoptosis induction by guggulsterone, a constituent of Ayurvedic medicinal plant Commiphora mukul, in PC-3 human prostate cancer cells is mediated by Bax and Bak. Mol. Cancer. Ther. 4: 1747-1754.

Tanguay S, Awde M, Brock G, Casey R, et al. (2009). Diagnosis and management of benign prostatic hyperplasia in primary care. Can. Urol. Assoc. J. 3: S92-S100.

Thompson IM (2001). Pharmacologic agents in complementary medicine in prostatic disease. Drugs Today 37: 427-433.

Wilt T, Ishani A, MacDonald R, Stark G, et al. (2000). Beta-sitosterols for benign prostatic hyperplasia. Cochrane Database Syst. Rev. 2000: CD001043. 